\title{
Uji Sensitivitas Skema Parameterisasi Cumulus untuk Prediksi Hujan di Wilayah Jawa Timur
}

\author{
Apritarum Fadianika* dan Hariadi \\ Jurusan Meteorologi, Sekolah Tinggi Meteorologi Klimatologi dan Geofisika (STMKG), \\ Jl. Perhubungan I No. 5, Pondok Betung, Bintaro, Tangerang 15211
}

Intisari

\begin{abstract}
Tidak setiap proses di atmosfer dapat diselesaikan secara eksplisit oleh persamaan gerak dalam model numerik. Dengan demikian, setiap model NWP termasuk WRF menggunakan parameterisasi untuk parameter cuaca yang tidak dapat dihitung langsung oleh rumus matematika. Salah satu parameterisasi di WRF-ARW adalah parameterisasi cumulus. Uji Kain-Fritsch (KF), Betts-Miller-Janjic (BMJ), Grell-Devenyi (GD) dilakukan untuk meningkatkan akurasi prediksi hujan dengan memilih skema parameterisasi kumulus yang memiliki sensitivi- tas tertinggi. Skema ini dibandingkan spasial untuk menentukan kesesuaian dalam lingkup kabupaten atau kota, dan diverifikasi pada tujuh poin dari stasiun BMKG di Jawa Timur untuk mendapatkan perkiraan akurasi. Berdasarkan perbandingan dan verifikasi antara hasil model dan data pengamatan, umumnya, skema GD adalah yang terbaik skema cumulus parameterisasi di hampir seluruh wilayah Jawa Timur, kecuali di Pulau Bawean (BMJ) dan Tuban, Panarukan, dan Banyuwangi (KF). Kinerja model WRF-ARW cukup baik memprediksi hujan atau tidak hujan kejadian (rata-rata Proportion Correct (PC) di atas 0,7), tetapi tidak dapat memprediksi secara tepat waktu kejadian dan intensitas hujan. Model ini cenderung meremehkan tetapi mendekati prediksi nyata (Equitable Threat score value (ETS) di bawah 0,2 dan rata-rata Frequence Bias Index (FBI) 0,6).
\end{abstract}

\begin{abstract}
Not every process in the atmosphere can be solved explicitly by the equations of motion in numerical models. Thus, every NWP models including WRF uses a parameterization for weather parameters that cannot be calculated directly by mathematical formula. One of parameterization in WRF-ARW is a cumulus parameterization. The test of Kain-Fritsch (KF), Betts-Miller-Janjic (BMJ), Grell-Devenyi (GD) schemes are conducted to increase the accuracy of rain prediction by selecting the cumulus parameterization scheme that has the highest sensitivity. The scheme was compared spatially to determine the suitability in a scope of the district or city, and verified at seven points of BMKGs station in East Java to obtain the forecast accuration. Based on the comparison and verification between model results and observational data, generally, GD scheme is the best cumulus parameterization scheme in almost whole area of East Java, except in Bawean Island (BMJ) and Tuban, Panarukan, and Banyuwangi (KF). WRF-ARW model performance are quite good at predicting rain or not rain occurence (the average of Proportion Correct (PC) is above 0.7 ), but it cannot precisely predict the time of occurence and intensity of the rain. The model tend to underestimate but it approach the real prediction (Equitable Threat score value (ETS) under 0.2 and the average of Frequence Bias Index (FBI) 0.6).
\end{abstract}

KATA KUNCI: NWP, WRF-ARW, cumulus parameterization, PC, ETS, FBI

\section{PENDAHULUAN}

Research WRF (WRF-ARW) merupakan model generasi lanjutan sistem simulasi cuaca numerik skala meso yang didesain untuk melayani simulasi operasional dan kebutuhan penelitian atmosfer. WRF cocok untuk aplikasi yang luas dari skala meter sampai ribuan meter [1]. Advanced Research WRF (ARW versi 2.1.1) merupakan model yang mendukung beberapa parameterisasi, diantaranya adalah parameterisasi cumulus yang terpisah: Kain-Fritsch (KF) [2], BettsMiller-Janjic (BMJ) [3] dan skema ensemble Grell-Devenyi

\footnotetext{
*E-MAIL: fadianika@gmail.com
}

(GD) [4]. Setiap parameter mempunyai pengaruh tersendiri terhadap hasil prediksi model. Pemilihan skema parameterisasi yang baik dapat mempengaruhi keakuratan dalam prediksi. Parameterisasi cumulus ini diperlukan untuk menjelaskan proses pembentukan hujan di dalam model. Hal ini jelas sangat penting untuk mengkaji fenomena hujan [5].

Parameterisasi adalah cara menghitung secara implisit efek proses-proses fisis yang secara eksplisit tak dapat direpresentasikan dalam model dengan variabel-variabel yang telah diperhitungan dalam model. Alasan parameterisasi dilakukan karena komputer belum cukup mampu untuk memanipulasi banyak proses yang terlalu kecil atau sangat kompleks serta karena banyak proses fisis di atmosfer tak dapat dimodelkan secara eksplisit karena kurangnya pengetahuan tentang bagaimana proses-proses bekerja untuk diformulasikan secara 
matematik atau karena tidak ada data.

Skema parameterisasi konvektif atau parameterisasi cumulus berguna untuk mengurangi ketidakstabilan termodinamik sehingga presipitasi dalam skala grid dan skema parameterisasi awan (microphysic parameterization) tidak menimbulkan konveksi skala luas yang tidak realistik dan mencegah terjadinya cyclogenesis lapisan bawah yang terlalu aktif. Skema parameterisasi cumulus dapat mengurangi ketidakstabilan dengan mengatur suhu dan kelembapan dalam kolom grid [6].

Skema KF pertama berasal dari skema parameterisasi konvektif Fritsch-Chappell. Skema KF digunakan untuk memprakirakan ketidakstabilan cuaca dan keadaan yang menyebabkan pertumbuhan awan konvektif terjadi. Skema ini menggunakan model awan sederhana dengan memperhitungkan kelembapan, updraft dan downdraft, entrainment dan detrainment serta proses mikrofisis sederhana [7]. Pada dasarnya skema KF mengatur ulang massa di kolom menggunakan updraft, downdraft, dan fluks massa lingkungan sampai setidaknya $90 \%$ dari CAPE (Convective Available Potential Energy) dihapus. CAPE dihitung dengan cara tradisional, menggunakan kenaikan parsel yang tidak dicairkan (undiluted), dengan karakteristik parsel seperti pada USL. Skema memberi feed back pada kecenderungan konvektif dari temperatur, $m i$ xing ratio uap air, dan mixing ratio awan.

Pada skema parameterisasi cumulus BMJ, asumsi yang digunakan dalam skema BMJ adalah sebagai berikut: terdapat struktur termodinamika quasiequilibrum dimana lingkungannya berpindah akibat konveksi. Struktur ini dapat didefinisikan dalam mixing line yang ditentukan dari data observasi; untuk tujuan representasi konveksi dari model global, hal tersebut tidak penting untuk secara ekplisit menampilkan pemanasan dan kelembaban yang disebabkan oleh proses subgrid updraft, downdraft, peluruhan dan pembentukan. Dengan asumsi bahwa kesederhaan desain akan lebih efisien dan mengurangi eror, semuanya dibuat secara implisit; batas skema diasumsikan bahwa laju saat kelabilan konvektif ditimbulkan dalam suatu lingkungan yang menentukan bagaimana kecepatan profil lingkungan berubah menurut mixing-line. Skala waktu relaksasi untuk konvektif selama 2 jam.

Skema parameterisasi cumulus GD memperkenalkan skema ensemble cumulus pada keefektivan skema multiple cumulus, variasi dijalankan pada setiap grid kemudian hasilnya dirata-rata untuk mendapatkan umpan balik ke model. Asumsi yang digunakan dalam skema GD adalah awan konveksi dalam untuk semua grid, skema awal berasal dari fungsi cloud-work Arakawa-Schubert untuk batasnya, tetapi kemudian berubah menggunakan CAPE sebagaimana KainFritsch, dan tidak ada pencampuran langsung secara lateral dengan lingkungan, kecuali pada level awal atau akhir dari updraft/downdraft sehingga fluks massa konstan menurut ketinggian. Kelebihan dari skema GD diantaranya, skema ini merupakan skema yang sangat sempurna yang dimodifikasi sehingga seperti Kain-Fritsch [8], memasukan efek downdraf, dan sangat baik untuk ukuran grid $10-12 \mathrm{~km}$.

Beberapa penelitian untuk menguji skema parameterisasi pada model WRF-ARW telah dilakukan baik di dunia ataupun di Indonesia, diantaranya oleh: Gilliland [8]; Mercader [9]; serta Yavichan [10] yang menguji ketiga skema parameterisasi tersebut di Nebraska, Catalonia, dan South Thailand dengan memperoleh hasil bahwa skema Kain-Fritch paling baik digunakan untuk simulasi pada daerah tersebut. Sedangkan di Indonesia telah dilakukan pengujian ketiga skema tersebut, juga dilakukan untuk melihat sensitivitas parameterisasi antara lain dilakukan oleh Santriyani [2] yang menghasilkan bahwa skema Grell-Devenyi merupakan skema terbaik dalam analisa hujan ekstrim di Jakarta, pengujian skema dilakukan juga oleh Ginting [7] dengan hasil skema BMJ merupakan skema terbaik dalam kejadian angin kencang di Makassar, dan penelitian oleh Kurniawan, [11] yang meneliti wilayah Surabaya (Juanda) dan Jakarta (Cengkareng) dengan hasil bahwa skema BMJ merupakan skema terbaik digunakan dalam prakiraan hujan di Surabaya, serta GD dan KF baik untuk digunakan di Jakarta [11]. Dari berbagai penelitian tersebut, terlihat bahwa perbedaan pemilihan skema parameterisasi terbaik pada tiap kejadian menghasilkan nilai yang berbeda pada masing-masing daerah.

Penelitian ini perlu dilakukan mengingat belum adanya pengujian terhadap sensitivitas skema parameterisasi cumulus untuk digunakan sebagai bahan analisa ataupun prediksi cuaca di seluruh wilayah Jawa Timur sebelumnya, dengan tujuan untuk mempelajari sistem pemodelan WRF-ARW dan cara pengoperasiannya untuk diaplikasikan dalam prakiraan hujan di wilayah Jawa Timur dan membandingkan skema parameterisasi cumulus untuk melihat sensivitasnya terhadap luaran model, diharapkan dapat diketahui parameterisasi cumulus yang paling sesuai untuk digunakan dalam prediksi hujan di wilayah Jawa Timur. Serta untuk mengetahui performa model WRF-ARW dalam memprediksi hujan di Jawa Timur dengan memverifikasi dengan data observasi untuk melihat nilai keakuratan model. Hasil dari penelitian ini diharapkan dapat memperoleh skema parameterisasi cumulus yang paling sesuai untuk peningkatan kualitas analisa dan prediksi kejadian hujan di seluruh wilayah Jawa Timur.

\section{METODE PENELITIAN}

\section{A. Data}

Data utama yang digunakan dalam penelitian in adalah data GFS (Global Forecast System) yang menjadi nilai awal dalam prediksi dengan model WRF dan data observasi parameter hujan setiap 3 jam untuk tujuh Stasiun BMKG yang menjadi sampel di Jawa Timur yang didapat dari CMSS BMKG, serta data hujan harian di 161 titik pos hujan di seluruh wilayah Jawa Timur yang didapat dari Stasiun Klimatologi Karangploso Malang dengan tanggal kejadian:

- 12 Januari 2013

- 14 Februari 2013

- 13 Maret 2013

- 5 April 2013 
- 24 Mei 2013

- 6 Juni 2013

- 10 Juli 2013

- 10 Agustus 2013

- 2 September 2013

- 29 Oktober 2013

- 19 November 2013

- 26 Desember 2013

GFS adalah model prediksi cuaca numerik global yang dijalankan oleh The National Oceanic and Atmospheric Administrations (NOAA). Dalam penelitian ini data yang digunakan adalah GFS 4 yang memiliki resolusi $0,5^{\circ} \times 0,5^{\circ}$ atau sekitar $55,5 \mathrm{~km} \times 55,55 \mathrm{~km}$ yang di-downscale menjadi resolusi $6 \mathrm{~km}$. Data diambil dengan mengunduh dari web http://nomads.ncdc.noaa.gov/data/gfs4/. Data GFS yang digunakan adalah data forecast (36 jam) dari waktu inisialnya sehari sebelumnya dengan inisial pukul 12.00 UTC. Forecast dilakukan dengan spin-up time 12 jam agar model stabil.

Lokasi penelitian yang dipilih adalan Propinsi Jawa Timur. Lokasi ini menarik untuk dipilih mengingat wilayah Jawa Timur tidak hanya terdiri dari daratan yang luas sebagai bagian dari pulau Jawa, juga terdiri dari pulau yang terpisah dari pulau utama, yaitu Pulau Bawean dan Pulau Madura. Secara umum karakteristik hujan dipengaruhi oleh monsun, namun pada beberapa wilayah tertentu lebih dominan dipengaruhi oleh skala lokalnya. Perbandingan secara spasial dilakukan untuk seluruh kabupaten/kota di Jawa Timur, sedangkan untuk penentuan uji akurasi di titik stasiun BMKG di Jawa Timur, dilakukan di:

1. Stasiun Meteorologi Juanda Surabaya (112,748 BT \& 7,384 LS)

2. Stasiun Meteorologi Perak I (112,72 BT \& 7,22 LS)

3. Stasiun Maritim Perak II (112, 78 BT \& 7,38 LS)

4. Stasiun Klimatologi Karangploso (112,58 BT \& 7,75 LS)

5. Stasiun Meteorologi Banyuwangi (114,31 BT \& 8,2 LS)

6. Stasiun Meteorologi Kalianget (113,93 BT \& 7,05 LS)

7. Stasiun Meteorologi Sangkapura Bawean (112,65 BT \& 5,85 LS)

Penentuan waktu penelitian dilakukan setiap bulan dengan mengambil contoh satu hari. Pemilihan hari dilakukan dengan melihat sebaran hujannya. Penentuan (kasus) didasarkan dengan melihat variasi curah hujan yang terjadi pada hari tersebut (diusahakan jatuh pada hari dimana terdapat curah hujan yang rendah di suatu daerah atau bahkan tidak hujan hingga terukur curah hujan dengan intensitas tinggi di daerah lain

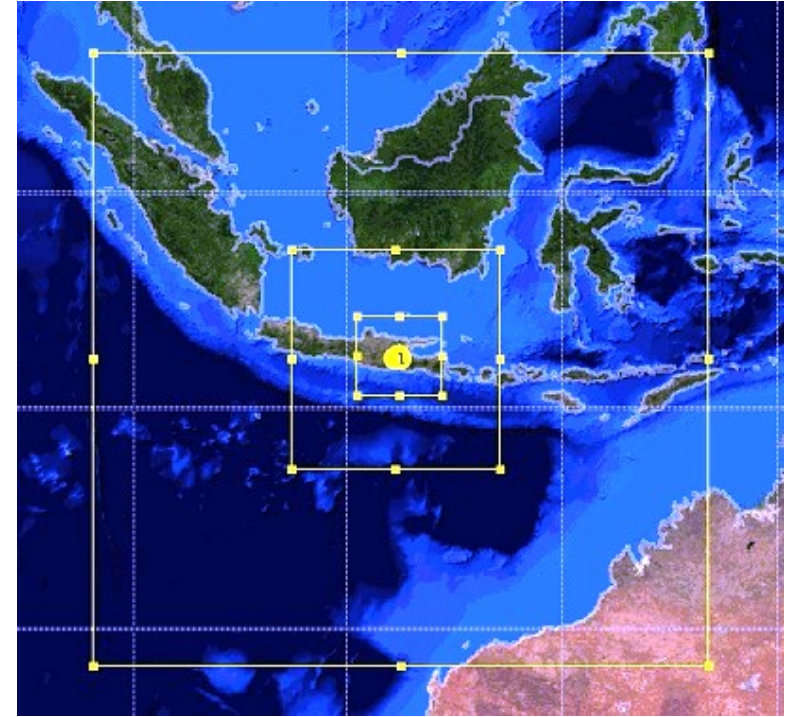

Gambar 1: Domain penelitian.

TABEL I: Konfigurasi WRF-ARW.

\begin{tabular}{|c|c|}
\hline PUSAT LINTANG & 7,59 LS \\
\hline PUSAT BUJUR & $122,857 \mathrm{BT}$ \\
\hline SKEMA MIKROFISIK & Kessler \\
\hline SKEMA RADIASI & RRTM (Rapid Radiation \\
\hline GEL. PANJANG & Transfer Model) Scheme \\
\hline $\begin{array}{l}\text { SKEMA RADAIASI } \\
\text { GEL. PENDEK }\end{array}$ & Dudhia \\
\hline OPSI LAP. PERMUKAAN & MM5 \\
\hline OPSI PERMUKAAN DARAT & NOAH Land Surface \\
\hline OPSI LAP. BATAS (PBL) & YSU \\
\hline OPSI CUMULUS & KF, BMJ, GD Scheme \\
\hline SUMBER INPUT PERMUKAAN & WPS/geog \\
\hline UPDATE DATA SST & No SST Update \\
\hline
\end{tabular}

pada musim hujan dan masa transisi). Sedangkan pada bulanbulan tidak hujan, pemilihan kasus didasarkan pada hari dimana di seluruh Jawa Timur tidak hujan. Diharapkan dengan pemilihan tersebut dapat menunjukkan kesensitivitasan model dalam menunjukkan sebaran pola dan intensitas yang berbeda dalam prakiraannya.

\section{B. Metode}

Pengolahan data dilakukan secara kuantitatif dan kualitatif. Running model WRF-ARW dengan input data GFS. Pengaturan model dengan resolusi spasial: 54, 18, dan $6 \mathrm{~km}(d y$ namic downscaling dengan nesting) dengan domain penelitian seperti ditunjukkan Gambar 1, dan konfigurasi model seperti ditunjukkan Tabel I.

Hampir keseluruhan pemilihan parameterisasi adalah $d e-$ fault dari model, kecuali untuk parameterisasi mikrofisik Kessler dipilih karena parameterisasi ini merupakan parameterisasi mikrofisik yang dianggap sesuai dengan jenis dan kondisi awan yang terjadidi daerah tropis (awan hangat). Se- 
TABEL II: Tabel kontingensi.

\begin{tabular}{cccc}
\hline \hline Prakiraan & \multicolumn{2}{c}{ Observasi } & Total \\
& Ya & Tidak & \\
\hline Ya & Hit & False Alarm & Fct "Ya" \\
Tidak & Miss & Corr. Non-event & Fct "Tidak" \\
Total & Obs "Ya" & Obs "Tidak" & Jumlah Total \\
\hline \hline Ya & A & B & $\mathrm{a}+\mathrm{b}$ \\
Tidak & $\mathrm{C}$ & $\mathrm{D}$ & $\mathrm{c}+\mathrm{d}$ \\
Total & $\mathrm{a}+\mathrm{c}$ & $\mathrm{b}+\mathrm{d}$ & $\mathrm{n}=\mathrm{a}+\mathrm{b}+\mathrm{c}+\mathrm{d}$ \\
\hline \hline
\end{tabular}

lain itu, pemilihan skema YSU pada parameterisasi lapisan batas atmosfer berdasarkan pada penelitian yang dilakukan oleh Rizkiana [12] bahwa skema YSU merupakan penyempurnaan dari MRF, dimana diketahui bahwa skema MRF baik digunakan di daerah tropis [13]. Sedangkan parameterisasi cumulus KF, BMJ, GD meruapakan parameterisasi yang diuji.

Analisis umum hasil luaran model terhadap data observasi, meliputi pola sebaran hujan dan perbedaan nilai curah hujan menggunakan analisis spasial dengan pemilihan teknik interpolasi Inverse Distance Weighted (IDW)[14] yang pilihannya telah tersedia dalam aplikasi ArcGIS. Persamaan interpolasi IDW yang digunakan adalah :

$$
x=\frac{\sum_{i=1}^{n}\left(\frac{Z_{i}}{D_{i}}\right)}{\sum_{i=1}^{n}\left(\frac{1}{D_{i}}\right)}
$$

dengan $\mathrm{x}=$ nilai interpolasi; $\mathrm{Z}_{i}=$ nilai data, $\mathrm{n}$ berada pada daerah sekitar $\mathrm{Z} ; \mathrm{D}_{i}=$ jarak antara $\mathrm{x}$ dan setiap data point.

Perbandingan kuantitatif data hasil luaran model WRFARW dengan data observasi untuk melihat akurasi model di 7 titik stasiun BMKG terpilih di Jawa Timur dengan menggunakan metode Equitable Threat Score (ETS), Proportion Correct (PC), dan Frequence Bias Index (FBI).

Pada tabel kontingensi (Tabel II), kejadian dianggap hujan apabila curah hujan observasi ataupun prakiraan $>1 \mathrm{~mm}$.

\section{Equitable Threat Score (ETS)}

$$
E T S=\frac{a-a_{r}}{a+b+c-a_{r}}, \quad a_{r}=\frac{(a+b)(a+c)}{n}
$$

dengan $\mathrm{a}_{r}=$ nilai hit referensi random. Merupakan evaluasi tingkat kebenaran prediksi kejadian hujan kategorikal dalam hal ini hujan /tidak hujan. Kisaran ETS: -1/3 - 1, dengan nilai $1=$ prediksi kejadian hujan sempurna dan nilai $\leq 0=$ prediksi tidak mempunyai skill.

\section{Proportion Correct (PC)}

$$
P C=\frac{a+d}{a+b+c+d}
$$

Merupakan prosentase prakiraan yang benar baik hit maupun correct non event. Kisaran PC : 0 1, dengan niai 1 = prediksi keseluruhan sempurna dan nilai 0 adalah batas ketidakmampuan prediksi

\section{Frequence Bias Index (FBI)}

$$
F B I=\frac{a+b}{a+c}
$$

Evaluasi terhadap bias prediksi kejadian hujan untuk mengetahui sifat model (over/underforecast) terhadap observasi. Kisaran B: 0 tak terhingga dengan nilai $1=$ prediksi sempurna, nilai $>1=$ overforecast dan nilai $<1=$ prediksi $u n$ derforecast [15].

Alur kerja penelitian ditunjukkan pada Gambar 2.

\section{HASIL DAN PEMBAHASAN}

\section{A. Perbandingan Spasial}

Hasil luaran model WRF ARW berupa file dengan ekstensi (.ctl) selanjutnya diplot unsur curah hujannya (berupa hujan total selama 24 jam) pada tanggal-tanggal kejadian. Dari hasil luaran model dalam GrADs tersebut, selanjutnya diubah dalam bentuk shapefile yang telah tersedia dalam perangkat lunak GrADs untuk dapat dipetakan menggunakan ArcGIS. Dengan menggunakan metode Spatial Analysis (Math) pada ArcGIS, didapatkan peta sebaran hujan baru yang menunjukkan selisih antara hujan sebenarnya dari hasil observasi dikurangi hujan dari luaran model WRF ARW. Tabel III menampilkan contoh peta hasil perbandingan antara luaran model dan observasi untuk tiap skema parameterisasi cumulus. Nilai negatif pada peta menunjukkan bahwa model overestimate atau model memprakirakan adanya hujan namun kenyataannya tidak (semakin negatif/semakin hijau berarti bahwa semakin overestimate curah hujan yang diprakirakan model) dan nilai positif menunjukkan bahwa model underestimate atau model memprakirakan tidak hujan sedangkan sebenarnya hujan (semakin positif/semakin merah menggambarkan bahwa semakin underestimate curah hujan prakiraan luaran modelnya). Selanjutnya, diasumsikan bahwa untuk range (-5 sampai dengan 5/warna kuning cerah) merupakan kisaran nilai yang menunjukkan bahwa model cukup baik dalam memprediksikan hujan di suatu wilayah.

Seperti kajian yang pernah dilakukan sebelumnya oleh Hanggoro [16] bahwa hasil perbandingan model dengan observasi menunjukkan hasil yang berbeda-beda dengan tingkat konsistensi yang kurang baik (model bisa underestimate, bisa overestimate).

Selain dengan membandingkan secara kualitatif tersebut, perbandingan juga dilakukan dengan menngeluarkan nilai rata-rata kisaran nilai (range perbandingan) di setiap kabupaten dengan asumsi bahwa semakin mendekati 0 nilai ratarata di daerah tersebut, maka skema parameterisasi yang dipilih merupakan skema yang terbaik. Pengolahan ini dilakukan dengan metode zonal statistic yang tersedia dalam pilihan spatial analysis tools dalam aplikasi ArcGIS. Maka dari 12 


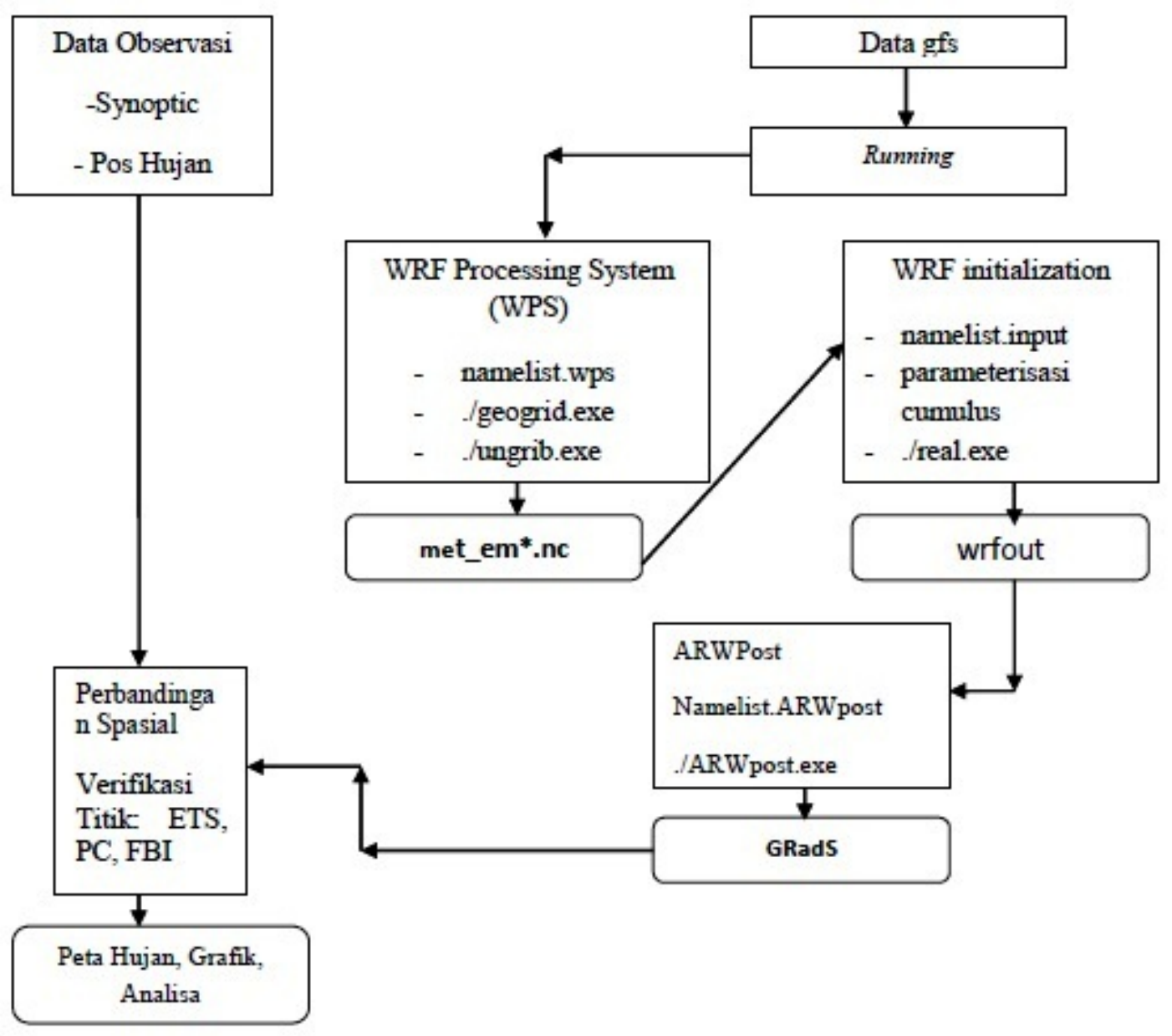

Gambar 2: Alur kerja penelitian.

hari kasus kejadian, akan didapatkan skema parameterisasi terbaik untuk digunakan dalam memprediksi kejadian hujan di 30 kabupaten di propinsi Jawa Timur dengan sebaran seperti ditunjukkan Gambar 3.

Prosentase menunjukkan perbandingan antara jumlah hari hujan (terjadi hujan saat sample kasus) di suatu kabupaten terhadap luaran model dengan skema parameterisasi cumulus yang dipilih. Artinya, semakin besar prosentase di suatu kabupaten, menunjukkan semakin besar pula frekuensi skema tersebut dalam kepatan prediksi yang paling mendekati yang menunjukkan kejadian hujan yang sebenarnya di kabupaten tersebut.

Di Kabupaten Bawean, dalam hal ini hanya terdapat satu titik pengamatan/pos hujan, sensitivitas skema BMJ menunjukkan nilai $100 \%$ mendekati keadaan sebenarnya. Sesuai dengan kajian yang dilakukan oleh Ginting [7] bahwa skema BMJ mempunyai batas mixing line yang cocok untuk digunakan di laut tropis, dan Pulau Bawean merupakan pulau yang relatif kecil yang di apit oleh lautan, hal ini menyebabkan tingginya kandungan uap air di daerah tersebut. Oleh karena itu, skema parameterisasi kumulus yang paling efektif digunakan adalah skema BMJ dimana pemicu konveksi pada skema BMJ salah satunya adalah kelembaban udara.
Daerah dengan kelembaban udara tinggi dapat mengalami konveksi. Pada saat terjadi konveksi parsel udara naik ke atas mengalami pendinginan adiabatik dan melepaskan sejumlah panas ke lingkungan sekitarnya. Panas tersebut memanaskan parsel udara lainnya sehingga terjadi konveksi yang lebih besar. Meningkatnya konveksi akan menurunkan tekanan di permukaan karena densitas udara yang semakin rendah. Massa udara lain akan mengisi kekosongan udara yang ditimbulkan konveksi.

Secara umum, GD merupakan skema yang paling baik dalam menunjukkan hujan, hal ini terlihat pada Gambar 3 dimana 26 dari 30 (sekitar 86,7\%) wilayah kabupaten di Jawa Timur cocok menggunakan skema ini dalam memprakirakan hujan. Dan untuk kejadian hujan dengan intensitas sedang sampai dengan sangat lebat yang terjadi di beberapa daerah diwilayah Jawa Timur pada sample, GD merupakan skema terbaik dalam menunjukkan kejadian tersebut.

Sedangkan untuk skema KF, sensitivitasnya paling baik dibandingkan dua skema lainnya di tiga kabupaten, yaitu di kabupaten Tuban, Situbondo, dan Banyuwangi. Daerah tersebut merupakan daerah yang berada di pesisir Pantai Utara Jawa dan pesisir Selat Bali. Hal ini sesuai karena skema KF menunjukkan adanya konveksi dalam satu grid yang dise- 


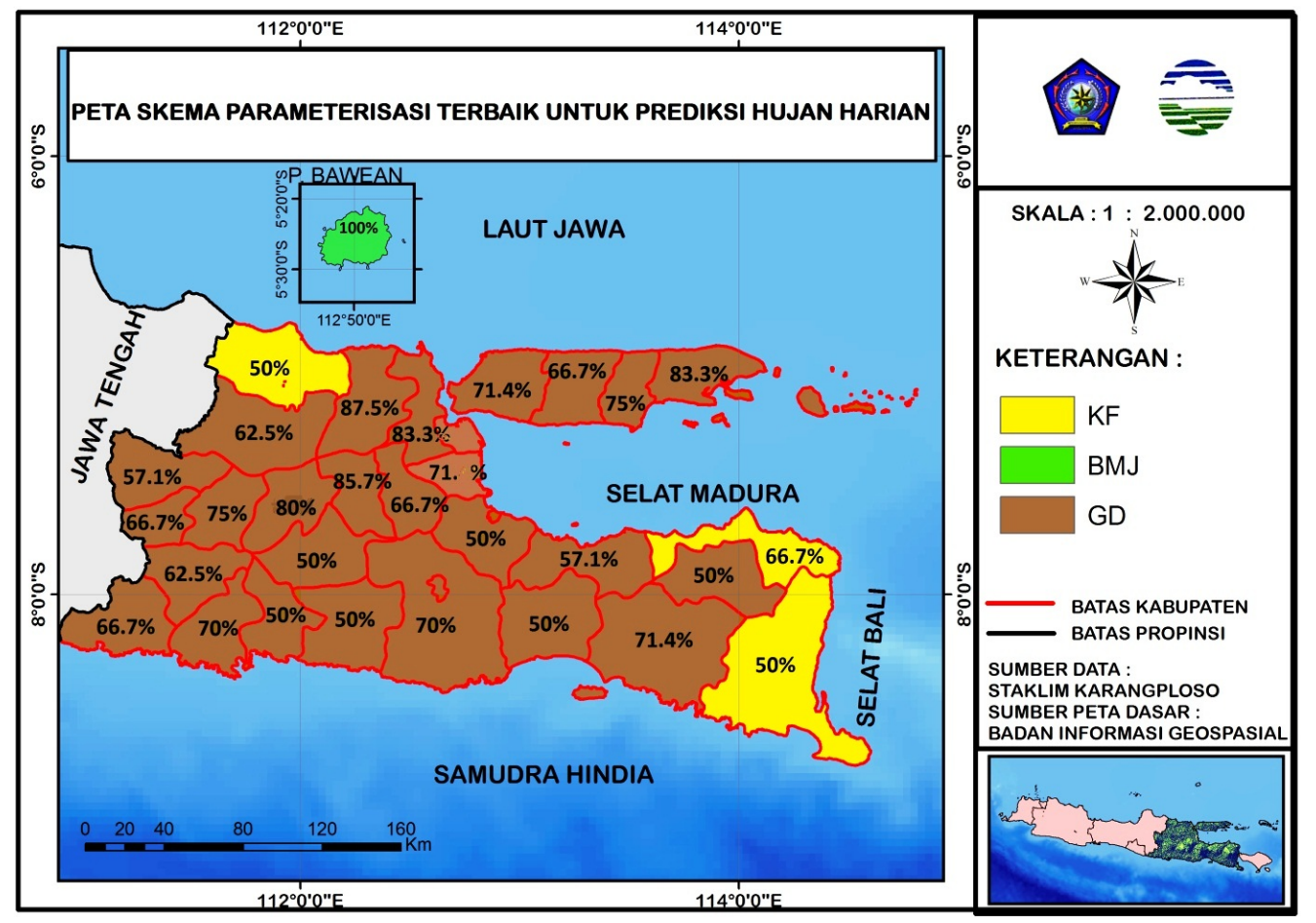

Gambar 3: Sebaran Skema Parameterisasi dengan Sensitivitas Terbaik di Wilayah Jawa Timur.

babkan oleh proses pembentukan awan konvektif yang terjadi pada skala lokal. Skema KF sensitif terhadap konveksi lemah yang terjadi pada suatu grid kecil. Dibandingkan dengan skema GD, hujan yang dihasilkan pada skema ini lebih sering merupakan hujan-hujan dengan sebaran sporadis yang terjadi menyebar pada grid-grid yang kecil. Disamping itu, terdapat sedikit perbedaan/anomali kejadian hujan pada ketiga kabupaten ini, dalam artian, ketika secara umum seluruh wilayah Jawa Timur hujan, pada daerah tersebut tidak hujan, sebaliknya, ketika pada umumnya daerah Jawa Timur tidak hujan, ketiga kabupaten tersebut hujan, kecuali pada kasus yang diambil pada bulan Januari (musim hujan), bulan Juni (masa transisi I), dan bulan Agustus-September (musim kemarau).

Pada kejadian hari tidak hujan $(86,8 \%$ dari 131 kejadian hari tidak hujan) di seluruh kabupaten di propinsi Jawa Timur, skema BMJ merupakan skema parameterisasi terbaik yang menunjukkan keadaan tersebut. Hal ini berbeda jika dibandingkan dengan skema GD ataupun KF yang lebih baik dalam menunjukkan kejadian hujan. Hal tersebut dikarenakan pada asumsi skema BMJ yang hanya berpengaruh terhadap kondisi permukaan secara tidak langsung, seperti melalui penguapan curah hujan dan pengurangan sinar matahari dari awan dan lebih sering bekerja dengan baik pada lingkungan yang lembab, jadi ketika lingkungan sekitar kelembapannya kecil, model akan menunjukkan kejadian tidak hujan, sedangkan untuk skema KF dan GD yang memperhitungkan nilai CAPE dan parameter lain, cenderung lebih mampu dan sensitif dalam memprakirakan hujan.

\section{B. Verifikasi Titik Stasiun BMKG}

Verifikasi untuk mengetahui performa dan akurasi model dilakukan di tujuh titik Stasiun BMKG di Jawa Timur, yaitu di Stasiun Meteorologi Juanda Surabaya, Stasiun Meteorologi Perak I Surabaya, Stasiun Meteorologi Perak II Surabaya, Stasiun Klimatologi Karangploso Malang, Stasiun Meteorologi Banyuwangi, Stasiun Meteorologi Kalianget Madura, dan Stasiun Meteorologi Sangkapura Bawean. Verifikasi dilakukan dengan menghitung nilai ETS, PC, dan FBI yang dilakukan untuk data hujan setiap tiga, enam, dan dua belas jaman. Hasil verifikasi model ditunjukkan Gambar 4.

Pada hasil verifikasi hujan tiga, enam, dan dua belas jaman, tidak terdapat perubahan nilai akurasi yang significant. Nilai verifikasi skema GD ditunjukkan terbaik di Stamet Juanda. Nilai ETS dan FBI lebih tinggi ditunjukn pada hasil akurasi dengan jangka waktu prediksi lebih panjang, namun untuk PC paling baik ditunjukkan pada prediksi hujan tiga jam-an.

Dari hasil verifikasi luaran model pada titik-titik stasiun BMKG di Jawa Timur dengan data observasi setiap tiga, enam, dan dua belas jam-an, dapat disimpulkan bahwa:

1. Skema parameterisasi cumulus Kainn-Fritch (KF) baik digunakan untuk prediksi hujan di Stamet Banyuwangi dengan nilai ETS terendah 0,07 pada prediksi dua belas jam-an dan tertinggi 0,149 pada prediksi enam jam-an. Nilai PC terendah 0,667 pada prediksi dua belas jam-an dan tertinggi 0.885 pada prediksi tiga jam-an. Nilai FBI terendah 0,5 pada prediksi tiga dan enam jam-an dan tertinggi 0,55 pada prediksi dua belas jam-an. Parameterisasi cumulus skema KF, meskipun menggunakan 
TABEL III: Contoh perbandingan hujan observasi dengan prediksi model.

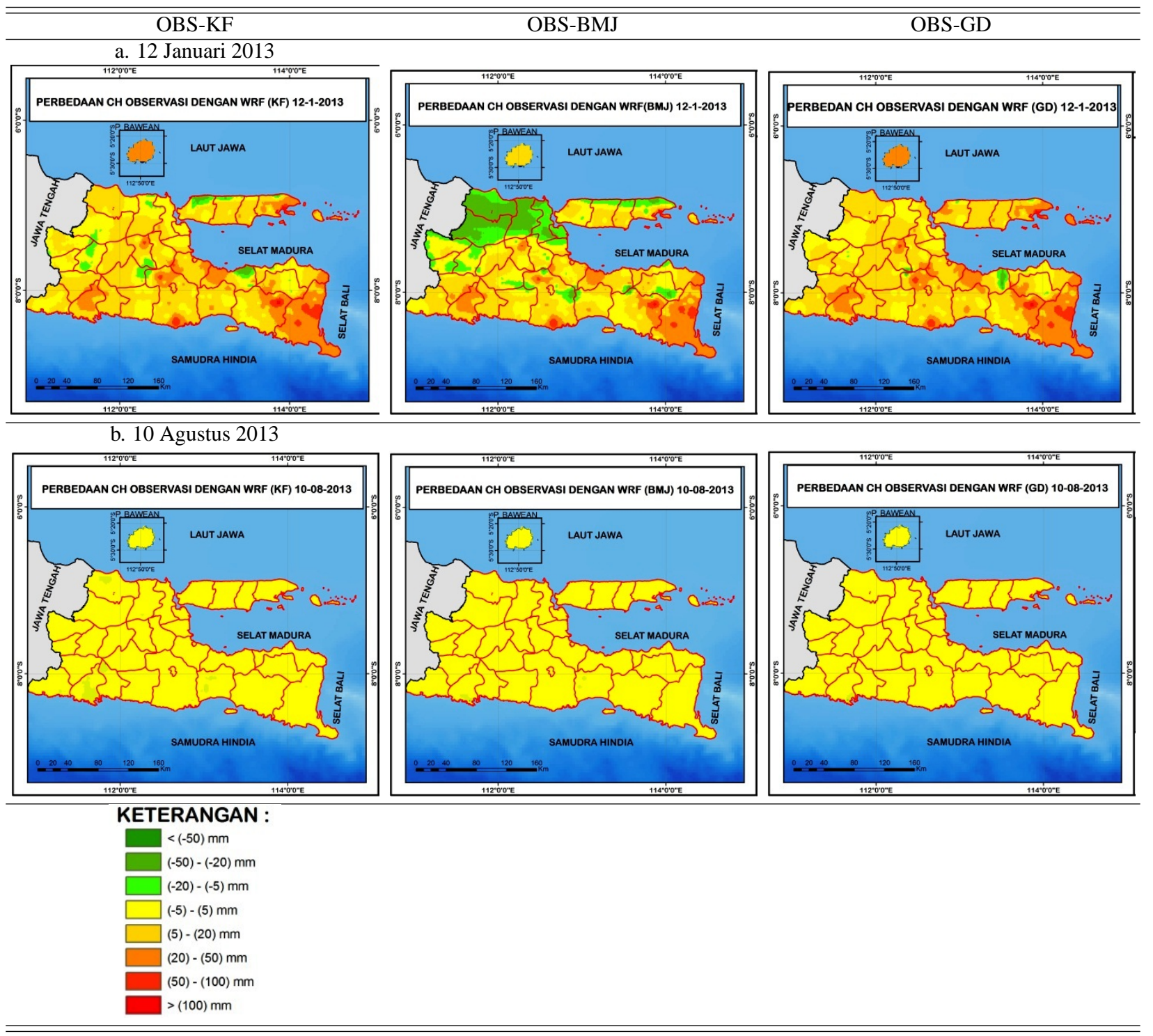

asumsi yang lebih kompleks, namun mampu merepresentasikan skala sub-grid terutama updraft dan skema pembentukan hujan. Alasan tersebut membuat skema KF lebih baik digunakan untuk menganalisa model realtime.

\section{Skema parameterisasi cumulus Betts-Miller- Janjic(BMJ)}

- Stamet Bawean dengan nilai ETS terendah 0,033 pada prediksi enam jam-an dan tertinggi 0,11 pada prediksi tiga jam-an. Nilai PC terendah 0.58 pada prediksi enam jam-an dan tertinggi 0,76 pada prediksi tiga jam-an. Nilai FBI terendah 1,5 pada prediksi dua belas jam-an dan tertinggi 2,19 pada prediksi tiga jam-an.

- Staklim Karangploso dengan nilai terendah ETS sebesar 0,288, PC terendah 0,78, dan FBI teren- dah 0,62 pada prediksi tiga jam-an dan nilai ETS tertinggi 0,348 , PC tertingggi 0,791 dan FBI tertinggi 1 pada prediksi enam jam-an.

3. Skema parameterisasi cumulus Grell-Devenyi (GD)

- Stamet Juanda dengan nilai ETS terendah 0,115 pada prediksi tiga jam-an dan tertinggi 0,318 pada prediksi dua belas jam-an. Nilai PC terendah 0,792 pada prediksi dua belas jam-an dan tertinggi 0,813 pada prediksi tiga jam-an. Nilai FBI terendah 0,62 pada prediksi tiga jam-an dan tertinggi 0,63 pada prediksi dua belas jam-an.

- Stamet Kalianget dengan nilai ETS terendah 0,034 pada prediksi enam jam-an dan tertinggi 0,073 pada prediksi tiga jam-an. Nilai PC terendah 0,583 untuk prediksi dua belas jam-an dan tertinggi 0,844 pada prediksi tiga jam-an. Nilai 


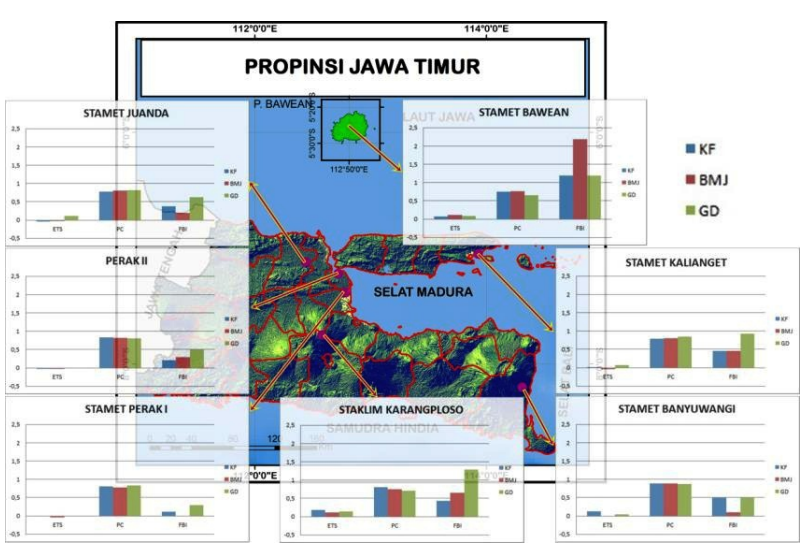

(a)

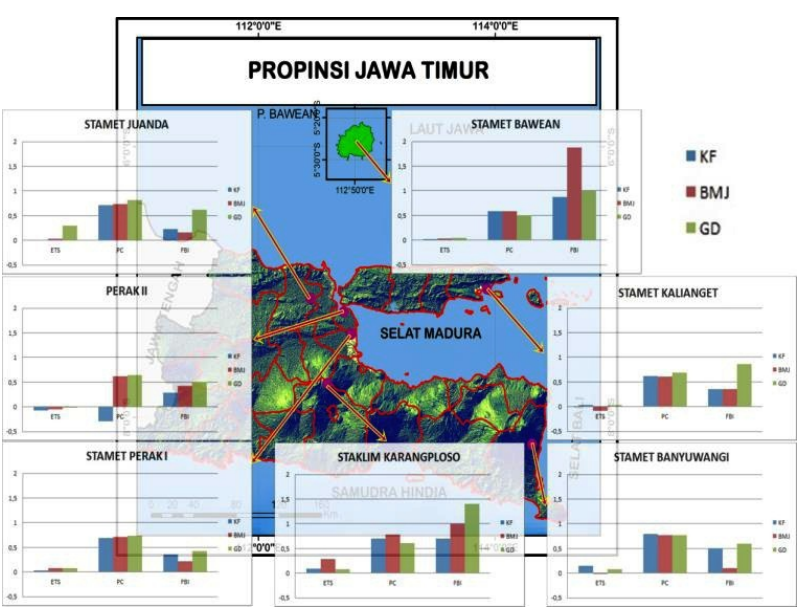

(b)

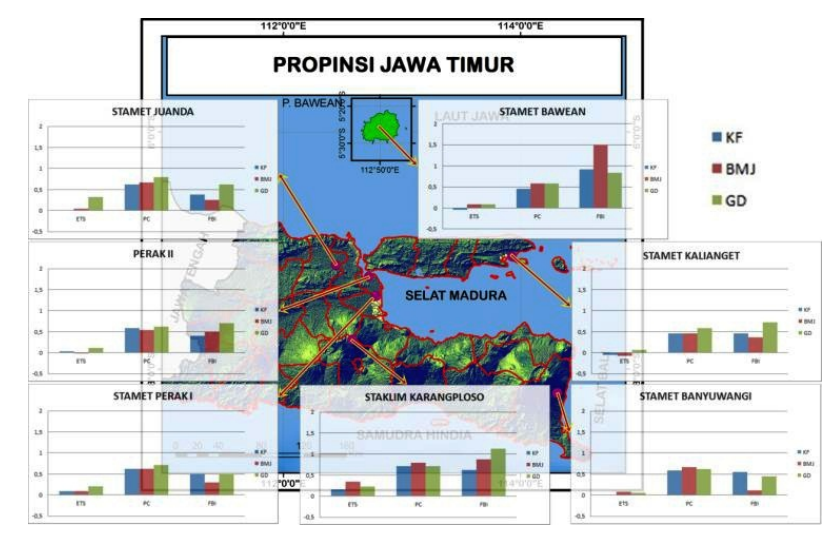

(c)

Gambar 4: (a) Verifikasi Titik Stasiun BMKG Jawa Timur per 3 jam-an dan (b) per enam jam-an (c) per dua belas jam-an

FBI terendah 0,73 pada prediksi dua belas jam-an dan tertinggi 0,92 pada prediksi tiga jam-an.

- Stamet Perak I dengan nilai ETS terendah 0 pada prediksi tiga jam-an dan tertinggi 0,08 pada prediksi enam dan dua belas jam-an. Nilai PC terendah 0,729 pada prediksi enam dan dua belas jam-an dan tertinggi 0,823 pada prediksi tiga jam-an. Nilai FBI terendah 0,30 pada prediksi tiga jam-an dan tertinggi 0,50 pada prediksi dua belas jam-an.

- Stamar Perak II dengan nilai ETS terendah -0,026 pada prediksi tiga jam-an dan tertinggi 0,032 pada prediksi dua belas jam-an. Nilai PC terendah 0,583 untuk prediksi dua belas jam-an dan tertinggi 0,823 pada prediksi tiga jam-an. Nilai FBI terendah 0,50 pada prediksi tiga dan enam jam-an dan tertinggi 0,70 pada prediksi dua belas jam-an.

Berdasarkan perbandingan spasial dan verifikasi titik, secara umum sensitivitas skema parameterisasi cumulus terbaik dalam verifikasi di suatu titik (dalam hal ini dicontohkan dengan pengambilan sample titik Stasiun BMKG) menunjukkan skema yang sesuai dengan perbandingan secara spasialnya. Namun, terjadi sedikit perbedaan antara pemilihan skema pa- rameterisasi cumulus yang sensitivitasnya lebih tinggi terhadap hujan di Stasiun Klimatologi Karangploso dibandingkan dengan perbandingan secara spasial. Stasiun Klimatologi Karangploso pada verifikasi titik paling baik menggunakan skema BMJ, namun pada perbandingan spasial setiap kabupaten, Kabupaten Malang paling sesuai menggunakan skema GD. Perbedaan hasil tersebut dapat terjadi karena pada penentuan skema terbaik secara spasial per kabupaten, nilai yang dihasilkan merupakan hasil interpolasi, sedangkan pada verifikasi titik, nilai yang didapat diperoleh dari data sebenarnya di titik tersebut tanpa interpolasi dengan titik lain. Selain itu, secara fisis, letak Staklim Karangploso yang berada di daratan tinggi dan faktor topografi yang menyebabkan di sekitar Staklim Karangploso suhunya cenderung dingin dan kelembapannya tinggi, menyebabkan skema yang sensitivitasnya tinggi terhadap titik tersebut adalah skema BMJ. Sedangkan untuk secara umum kabupaten Malang secara luas, skema GD merupakan skema dengan sensitivitas tertinggi dalam menunjukkan kejadian hujan. Dan khusus untukdi Stasiun Meteorologi Juanda Surabaya, hail ini berbeda dengan penelitian oleh Kunriawan pada bulan Agustus dan Februari 2012 yang mendapatkan hasil bahwa skema BMJ merupakan skema terbaik digunakan dalam prakiraan hujan dengan treath score tertinggi dibandingkan dua skema parameterisasi 
cumulus lainnya. Hal ini dimungkinkan karena pada pemilihan sample yang dilakukan oleh Kurniawan, data yang diverifikasi adalah data bulanan dan hanya dilakukan pada sample saat musim kemarau dan satu bulan sample pada musim hujan. Sedangkan pada penelitian ini, data penelitian merupakan kejadian harian (per event).

\section{SIMPULAN}

WRF ARW dapat digunakan sebagai salah satu model dalam memprediksi cuaca di Jawa Timur, baik untuk memprediksi dalam skala kecil ataupun memprediksi cuaca secara luas dengan pengaplikasian yang mudah. Dari perbandingan secara spasial se-Jawa Timur untuk parameter hujan, Skema Grell-Devenyi (GD) mempunya sensitivitas paling baik dalam memprakirakan hujan di seluruh wilayah Jawa Timur, kecuali di Pulau Bawean (Betts-Miller-Janjic/BMJ), dan tiga daerah di pesisir pantai utara Jawa, yaitu Kabupaten Tuban, Situbondo, dan Banyuwangi yang lebih cocok menggunakan skema parameterisasi Kainn-Fritch (KF). Berdasarkan hasil verifikasi untuk mengetahui performa model setiap tiga, enam, ataupun dua belas jam-an di tujuh titik stasiun BMKG, nilai ETS secara keseluruhan dapat dismpulkan bahwa model belum cukup mampu untuk menunjukkan kejadian hujan, namun nilai PC rata-rata diatas 0,7 (model telah cukup mampu menunjukkan hujan dan tidaknya suatu tempat), dan nilai FBI lebih banyak menunjukkan keadaan under-estimate dengan nilai bias rata-rata 0,6 yang berarti bahwa model lebih sering memprakirakan kejadian tidak hujan dibandingkan hujannya.

\section{Saran}

Dalam penggunaan model untuk prediksi ataupun analisa cuaca di Jawa Timur, jika prediksi dilakukan secara luas (propinsi) berdasarkan hasil penelitian ini, skema GD dapat digunakan sebagai opsi pemilihan parameterisasi cumulus yang digunakan. Jika prediksi dan kajian dilakukan pada daerah tertentu yang lebih sempit, hasil pemilihan skema per kabupaten/titik yang sebaiknya dipertimbangkan untuk digunakan. Untuk mengetahui kesesuaian model dengan karakteristik cuaca yang terjadi di suatu tempat, akan lebih baik jika uji sensitivitas parameterisasi cumulus dilakukan dengan waktu yang lebih panjang, sehingga dapat diperoleh prakiraan dengan akurasi yang lebih baik sesuai dengan karakteristik musimnya. Setiap daerah dan setiap kejadian hujan memiliki sensitivitas tersendiri dalam penggunaan parameterisasi cumulusnya. Oleh karena itu, penggunaan model untuk memprakirakan cuaca harus disesuaikan dengan karakteristik daerah yang akan dikaji.
[1] NCAR Technical Note 2005. (http://rda.ucar.edu, diakses tanggal 12 November 2013).

[2] J.S. Kain, M.E. Baldwin, and S.J. Weiss, Parameterized Updraft Mass Flux As A Predictor Of Convective Intensity ( Wea. Forecasting, in press, 2002).

[3] A.K. Betts, and M.J. Miller, Amer. Meteor. Soc., 24, 107-121 (1993).

[4] G.A. Grell, and D. Devenyi, Geophys. Res. Lett., 29, 1693-1696 (2002).

[5] M. Santriyani, dkk. Sensitivitas Parameterisasi Konveksi Dalam Prediksi Cuaca Numerik Menggunakan Model WRF-ARW (Studi Kasus Hujan Ekstrim Di Jakarta Tanggal 7 April 2009), Institut Teknologi Bandung, Bandung, 2009.

[6] Precipitation Cloud. (http://www.meted.ucar.edu/nwp/modelprecipandclouds/, diakses tanggal 12 Desember 2013)

[7] S. Ginting, dkk., Pengaruh Parameterisasi Kumulus terhadap Simulasi Angin Kencang di Makassar dengan Menggunakan $W R F$, Institut Teknologi Bandung, Bandung, 2011.

[8] E.K. Gilliland, and C.M. Rowe, A Comparison Of Cumulus Parameterization Schemes In The WRF Model, University of Nebraska, Lincoln, Nebraska, 2007.

[9] J. Mercader, et al., Results Of The Meteorological Model WRF$A R W$ Over Catalonia, Using Different Parameterizations Of
Convection And Cloud Microphysics, Barcelona, 2011.

[10] S. Yavinchan, Journal of the Meteorological Society of Japan, 89A, 201-224 (2011).

[11] R. Kurniawan, dkk. Verifikasi Model Meteorologi Weather Research And Forecasting (WRF), Laporan Bulanan Hasil Penelitian Puslitbang 2012, hal.34, BMKG, Jakarta, 2012.

[12] D. Rizkiana, dkk., Perbandingan Skema Parameterisasi Dalam Simulasi Cuaca Numerik Menggunakan Model WRF-ARW Studi Kasus Hujan Ekstrim Di Balikpapan Tanggal 5 Juli 2008, Skripsi, Jurusan Meteorologi, ITB, Bandung, 2008.

[13] K. Anzhar, Kajian Lapisan Batas Planeter Berdasarkan Hasil Simulasi Model Meteorologi Skala Meso, Institut Teknologi Bandung, Bandung, 2006.

[14] UIOWA, (2012). (http://www.uiowa.edu/g̃eog/health/interp/inv.html, diakses tanggal 18 Desember 2013.

[15] WMO, ,Recommendations for the Verification and Intercomparison of QPFs and PQPFs from Operational NWP Models, Switzerland, 2008.

[16] W. Hanggoro, W. Iis, dan S.M. Erwin, Simulasi Hujan Ekstrim Pada Kejadian Banjir Di Mataram tanggal 10 Januari 2009 Menggunakan WRF-EMS, Badan Meteorologi Klimatologi dan Geofisika, Jakarta, 2012 